\title{
ANÁLISE DE UM DISCURSO POLÍTICO \\ (ASPECTOS RETÓRICOS)
}

\author{
Suani de Almeida Vasconcelos*
}

RESUMO: O presente trabalho possui por objetivo analisar alguns aspectos retóricos do discurso político "Exército: nem guarda pretoriana nem tropas da SS", de autoria do então Deputado Federal Francisco José Pinto dos Santos (Chico Pinto), proferido em 08 de agosto de 1972. A fim de atingir esse objetivo, tomouse, como aporte teórico, a Nova Retórica, principalmente os trabalhos desenvolvidos por Chaïm Perelman ou baseados neles. São analisados alguns processos argumentativos utilizados pelo Deputado em seu discurso, considerando as relações entre orador e auditório e a cena enunciativa.

PALAVRAS-CHAVE: Argumentação, Ethos, Retórica.

ABSTRACT: The present work aims at analyzing some rhetorical aspects of the political speech "Army: neither Praetorian Guard nor SS troops”, by the then Congressman Francisco José Pinto dos Santos (Chico Pinto), delivered on August 8, 1972. In order to reach that aim, this paper has adopted the New Rhetoric, as its theoretical framework, mainly the works developed by Chaim Perelman or the works based on his works. Some argumentative processes used by the Congressman in his speech are analyzed, by taking into account the relationships between speaker and audience and the utterance scene.

KEY WORDS: Argumentation, Ethos, Rhetoric. 
*Mestranda em Lingüística Aplicada - UFBA

Membro do Grupo de Edção de Textos - UEFS

\section{INTRODUÇÃO}

O presente trabalho insere-se na pesquisa de mestrado em desenvolvimento junto ao Programa da PPGLL da Universidade Federal da Bahia na área de Lingüística Aplicada, iniciado em 2003. Essa pesquisa tem por objetivo estudar alguns processos argumentativos utilizados pelo, então, Deputado Federal Francisco José Pinto dos Santos (Chico Pinto) em alguns dos seus discursos, proferidos entre 1972 e 1974, na Câmara dos Deputados (Câmara Legislativa Federal), possuindo como aporte teórico a Nova Retórica.

O discurso "Exército: nem guarda pretoriana nem tropas da SS" de 08 de agosto de 1972 faz parte de uma coletânea de outros discursos produzidos pelo ex-deputado Francisco Pinto, os quais se constituem num conjunto de produções que refletem a sua resistência política às opressões da Ditadura Militar, denunciando e revelando as ações da censura e do estado totalitário durante o período do governo dos Generais Emílio Garrastazu Médici e Ernesto Geisel, entre os anos de 1971 a 1974.

\section{CONTEXTO SÓCIO-HISTÓRICO}

Década de 60. O Brasil vivenciava um dos períodos mais difíceis e intransigentes da política brasileira: o golpe militar no ano de 1964, quando da deposição do, então, presidente João Belchior Marques Goulart, - Jango - e a tomada do poder pelas Forças Armadas.

Esse momento foi marcado por forte repressão às instituições democráticas como, por exemplo, a imprensa e aos veículos de comunicação, culminando com a extinção dos vários partidos políticos (criação do bipartidarismo: ARENA - Aliança Renovadora Nacional - e o MDB - Movimento Democrático Brasileiro), cassação de mandatos dentre outras medidas intervencionistas à vida política do país. Destarte, o golpe militar representou o 
esfacelamento da representatividade popular, uma vez que proibiu os movimentos sociais organizados, a exemplo de sindicatos e associações, os quais defendiam reformas de ordem política e institucionais, empreendidas pelo governo Jango. Conforme afirma HABERT (1994, p. 09), "o golpe militar foi uma reação das classes dominantes ao crescimento dos movimentos sociais mesmo tendo estes um caráter predominantemente nacional-reformista".

A criação dos Atos Institucionais, iniciados no governo do General Castelo Branco (1964-1967), foi outra medida repressiva de caráter intervencionista nas várias instâncias políticas e sociais, visando a manutenção da ordem através de perseguições, torturas e mortes daqueles considerados comunistas, terroristas e desordeiros pelo Serviço Nacional de Informação - SNI. Os Atos Institucionais foram implementados durante os anos subseqüentes ao golpe militar, tendo como objetivo a implantação concreta e sólida do regime ditatorial.

O AI 5 do governo Costa e Silva (1967-1969) configurou-se no mais repressivo instrumento de silenciamento dos vários segmentos da sociedade organizada, haja vista que o ano de 68 foi período no qual aconteceram os maiores protestos conta os abusos da ditadura, destacando-se os movimentos estudantis e operários. O AI5 deu poderes ilimitados ao chefe de Estado, outorgando-lhe decisões válidas e legítimas sem possibilidade de contestação que

permitiu-lhe fechar o congresso por tempo indeterminado, continuar a cassar mandatos, suspender por dez anos os direitos políticos de qualquer cidadão, demitir ou aposentar qualquer funcionário público civil ou militar, estender a censura prévia à imprensa e aos meio de comunicação (HABERT, 1994, p. 10).

Nesse contexto nacional, particularmente na Bahia, destacase o político Francisco José Pinto dos Santos que foi eleito como chefe do executivo na cidade de Feira de Santana, pelo partido oposicionista - PSD, com o seguinte slongan "Chico Pinto na Prefeitura é o povo governando", "numa campanha violenta e 
entusiasmada", segundo palavras do próprio político em entrevista cedida, para o presente trabalho, em 07 de abril de 2003. Tomou posse em abril de 1963 e foi deposto pela ditadura em maio do ano seguinte, exatamente por contestar os "impositivos" e "desmandos" advindos do regime militar, denunciando torturas e mortes de companheiros políticos, bem como criticando o regime de força daquele momento da vida política brasileira. A partir de sua deposição, foi preso e torturado, começando, assim, uma série de prisões e torturas que sofreria durante sua vida política e se estenderia até o seu mandato de deputado federal pelo MDB, já na década de 70.

Os governos dos generais presidentes Emílio Garrastazu Médici (outubro/69 a março/74) e Ernesto Geisel (março/74 a março/78) deram continuidade ao processo iniciado com o golpe militar de 64, destacando, nesse período, o aumento da repressão política, do direito e da liberdade individual e de expressão, a exemplo da criação, pelos generais Médici e Orlando Geisel, irmão de Ernesto Geisel, do DOI (Destacamento de Operações de Informações) que, segundo GASPARI (2002, p. 174), "por mais de dez anos essas três letras foram símbolo da truculência, criminalidade e anarquia do regime militar".

Em março de 1970, Francisco Pinto toma posse como Deputado Federal pelo MDB, iniciando, assim, mais um período de fortes contestações frente aos presidentes generais e aos delitos cometidos em nome da preservação da integridade nacional. Nos quatro anos de mandato (1970/1974), denuncia abusos e autoridade por parte do governo instituído, através dos seus discursos proferidos nas sessões da Câmara dos Deputados, como, nos seguintes discursos, "Censura: A imagem do Medo", de 1973 e "Pinochet: o infame", de 1974, o qual lhe rendeu a cassação dos seus direitos políticos pelo Supremo Tribunal Federal, bem como uma prisão por agravo a uma autoridade internacional - Presidente do Chile - que estava no Brasil, naquela época, em visita. Em cárcere, no $1^{\circ}$ Batalhão da Polícia Militar do Distrito Federal, Chico Pinto, sabendo que receberia o indulto de natal do Presidente Ernesto 
Geisel, escreve-lhe um documento de repúdio ao indulto, alegando que tal medida seria cabível a um criminoso, e não para ele que não se enquadrava com tal.

Após sua liberação em abril de 1975, quatro meses a mais do prazo previsto de encarceramento, Francisco Pinto ingressa no Jornal O Movimento (SP/DF), em maio do mesmo ano, a convite do amigo Raimundo Pereira que participava do Jornal Opinião (RJ) para, assim, continuar seu trabalho de contestação às ações da ditadura militar. No ano seguinte, ingressa no grupo dos "autênticos" junto com outros militantes políticos do MDB.

Volta ao cenário político em 1978, quando elege-se a deputado federal (1978/1982) e, em 1985, participa, ao lado de Ulisses Guimarães, do movimento pela "Diretas Já". Cumpre outro mandato de deputado federal no período de 1986 a 1990, ainda pelo MDB, quando se afasta por definitivo da militância políticapartidária.

Hoje, reside em Brasília (DF), mas permanece vindo à sua terra natal, Feira de Santana, que, mesmo passado tanto tempo, ainda continua a ser lembrado como um símbolo do político forte e resistente, num período trevoso da vida brasileira, contra os desmandos da ditadura, até mesmo pelos seus opositores políticos.

\section{A RETÓRICA E A ARGUMENTAÇÃO}

Em seu sentido geral, a palavra retórica indica "a arte da utilização da linguagem para persuadir ou influenciar os outros" (BLACKURN,1997, p. 344). Outros autores consideram a retórica como arte de convencimento, definição que remonta à Antigüidade Clássica, tendo os Sofistas como seus representantes mais célebres. Posteriormente, Aristóteles lhe confere o caráter de 'ciência', dedicando-lhe um dos seus livros, intitulado Arte Retórica, estabelecendo seus princípios gerais e as suas divisões básicas quanto aos tipos de discursos retóricos. Sob essa perspectiva aristotélica, a retórica objetiva "descobrir os meios que, relativamente a qualquer 
argumento, podem levar a persuasão de um determinado auditório" (SERRA, 1995, p. 5).

Passado o período de esplendor da cultura greco-romana, a retórica vai, durante os séculos subseqüentes, perdendo seu poder de influência nos diversos campos do saber, reduzindo-se à mera disciplina que auxilia na construção de discursos. O declínio maior dá-se nos primórdios do século XVI com o avanço da tendência cartesiana e a ascensão do pensamento burguês.

$\operatorname{OSAKABE}(1999$, p. 150) analisa o ressurgimento da retórica no pensamento ocidental, salientando a figura de Chaïm Perelman que inicia o processo de retomada da dialética e da retórica com a publicação de uma obra significativa intitulada Tratado da Argumentacãa (1996). Esse livro questiona o cartesianismo ainda vigente como o único caminho ao conhecimento e estabelece uma reviravolta nos estudos relacionados a análise do discurso, pois retoma certas vertentes desvalorizadas pela secularização, a exemplo da natureza dialética do discurso. Ainda para OSAKABE (1999, p. 176), "trata-se de uma obra com finalidade polêmica, cujo objetivo é relativizar a tendência unilateral da lógica e da teoria do conhecimento de Descartes".

No tocante à tipificação dos discursos, estabelecida por Aristóteles, Perelman questiona essa classificação, preconizando a atemporalidade para a aplicação dos argumentos. Para ele, a "atemporalidade e a não compartimentalização dos fatos são fundamentais para conhecer a natureza complexa dos objetos" (OSAKABE, 1999, p. 178). O argumento, assim, adquire o status antes ocupado pelas evidências matemáticas e estendido às ciências humanas, ou seja, enquanto o discurso analítico não prescinde das demonstrações claras e evidentes para obter o convencimento dos ouvintes, minimizando a força argumentativa pelo caráter evidente dos fatos, a nova retórica elege o verossímil como o caminho possível à persuasão já que a verossimilhança propicia o caráter dialético das idéias na interlocução.

$\mathrm{Na}$ concepção perelmaniana, a retórica assume a posição de disciplina basilar no estudo e análise dos atos discursivos, uma vez 
que a retórica, desde o final da Antigüidade Clássica, teve o seu campo de ação progressivamente diminuído, apresentando alguma revivescência no Renascimento, pois, na Idade Média, "a retórica ficou sendo essencialmente a arte de apresentar verdades e valores já estabelecidos" (PERELMAN E OLBRECHTS-TYTECA,1996, p. 179).

Na Idade Moderna, as correntes de pensamento, particularmente os filósofos racionalistas e empiristas, refutaram a possibilidade de a retórica compartilhar seu campo de ação e de estabelecer-se como uma via de acesso ao conhecimento,

entretanto, faz uns vinte anos que assistimos a um lento renascimento da importância da retórica, e isso seguindo a direção das correntes filosóficas que, desde as filosofias da vida, da ação e dos valores, até o pragmatismo, marcaram a revivescência filosófica desde quase um século. (PERELMAN E OLBRECHTSTYTECA,1996, p. 180)

Perelman devolve à retórica o prestígio que desfrutava na Antigüidade Clássica, elegendo-a como essencial para a análise constitutiva do discurso. Em o Tratado da Argumentação, estabelece as idéias fundamentais, quanto a caracterização do argumento discursivo. Perelman então,

a) elege a verossimilhança, o plausível, o provável como pertencentes ao campo da argumentação;

b) refuta a idéia de evidência, na teoria da argumentação, pois

aquela limita a ação argumentativa;

c) defende as técnicas discursivas que permitem provocar $\mathrm{ou}$

aumentar a adesão dos espíritos às teses que lhes apresentam; 
d) ressalta a importância do auditório, pois é nele que o argumento se desenvolve;

e) afirma que todo discurso se dirige a um auditório.

A natureza do argumento, trazida pela Nova Retórica, rompe com o critério da prova, da evidência, já que estabelece a proximidade teórica com a dialética. Portanto, a oposição das teses constitutivas dos argumentos é o critério admitido para persuadir.

A relação estabelecida entre discurso e os constituintes da formação argumentativa, bem como as bases teoréticas que norteiam essas relações, serão elementos indispensáveis para a análise e estudo dos discursos que ora fazem parte desse projeto de pesquisa.

\section{O DISCURSO: PANORAMA GERAL}

Neste discurso, "Exército: nem guarda pretoriana nem tropas da SS", o político Francisco Pinto faz uma análise, profundamente marcada pelo caráter denunciador, da repressão e da censura instituídas pelo sistema ditatorial. As Forças Armadas, particularmente o exército brasileiro, é a temática central desse discurso, constituindo-se no sistema disciplinador daquele momento da história política do país.

É ressaltada a figura do General Augusto César Muniz de Aragão como um dos protagonistas do regime de força na manutenção da ordem e da disciplina. Resgata, também, trechos do discurso do general Muniz de Aragão, no qual ratifica o compromisso das Forças Armadas com o bem-estar social, quando afirma que as

Forças Armadas deveriam encontrar-se disciplinadas, adestradas e aptas, prontas para a ação contra o desrespeito a lei, a perturbação da harmonia entre as 
classes, e o exercício do arbítrio e a prática da violência (ARAGÃO: In.: PINTO, 1972, p. 02)

Utilizando-se dos discursos próprios do regime de força e opressão, Francisco Pinto reverte o sentido, naquele momento, de que as Forças Armadas deveriam estar prontas para o esmagamento das instituições democráticas; ao contrário, coloca-as como defensoras de tais instituições, ressaltando as condições necessárias para a caracterização de um estado de direito, onde "leis justas e legítimas existam e traduzam a média da consciência coletiva" (PINTO, 1972, p. 03).

O termo ditadura e tudo que a ele está ligado e se refere é contestado em todo discurso do ex-deputado, já que tanto a ditadura de direita ou de esquerda e daí a obediência ilimitada ao sistema político imposto, fazem obscurecer a participação popular nas decisões governamentais e, conseqüentemente, o fenecimento da democracia. A partir dessa postura, convoca a participação das Forças Armadas para exercerem de fato a missão que a elas compete, ou seja, combate à violência, e a garantia da segurança nacional, e não "para tornar-se milícia, guarda pretoriana ou tropa de assalto SS” (PINTO, 1972, p. 03). Adiante, completa seu argumento afirmando que, assim, "os oficiais da dignidade de guardiães da pátria, ver-se-iam levados à condição de beleguins ou inquisitores e, mesmo de sequazes ou esbirros de camarilhas sem fé e sem patriotismo" (PINTO, 1972, p. 03).

Nota-se, enfim, em todo o discurso, há defesa pelo estado democrático e de direito, no qual as leis sejam respeitadas e que a liberdade de opinião e de expressão sejam garantidas. Enfatiza a necessidade de que o exército deveria estar ao lado do povo e não contra este, no cumprimento das garantias constitucionais.

Querem estes governos que os militares sejam fiéis executores destas leis; e quando estes passam a impor ao povo o cumprimento de leis ditadas por minorias arbitrárias, eles se desviam de suas verdadeiras missões, esquecendo-se 'de suas nobres tradições' e deformando 
assim a prática de sua função constitucional, para tornar-se milícia, guarda pretoriana ou tropa de assalto da SS (PINTO, 1972, loc. cit.).

\section{CONTEXTO SITUACIONAL}

O AQUI da enunciação é o lugar social do qual o EU fala. Lugar esse de autoridade, pois a enunciação não pode vir de quem não foi legitimado a falar. Em questão, Francisco Pinto, enquanto deputado federal, eleito por votação direta, que fala com autoridade conferida pelo povo através da escolha popular (votação direta). Representante popular, usa do lugar social que ocupa para falar em nome de quem o elegeu para denunciar os abusos de autoridade das Forças Armadas, bem como defender os interesses de ordem social, ou seja, a liberdade de pensamento e expressão.

O AGORA corresponde ao momento da enunciação. Neste caso, diz respeito ao discurso "Exército: nem guarda pretoriana nem tropas da SS" de 18 de agosto de 1972, em pleno governo do General Emílio Garrastazu Médici, considerado general "linha dura" na condução do executivo. Esse discurso retrata a indignação do político Francisco Pinto frente às ações da Forças Armadas que, na verdade, deveriam estar ao lado do povo, protegendo-o e zelando pela segurança nacional e não esmagando as conquistas democráticas e sociais, a exemplo das perseguições e torturas.

\section{OS INTERLOCUTORES}

\subsection{O EMISSOR}

Neste discurso, o locutor (L) é representado por apenas uma pessoa, na voz do político Francisco Pinto que ocupa a posição de deputado federal a favor dos interesses populares. Esse EU não fala de maneira pessoal, isto é, na primeira pessoa do singular, mas, muitas vezes, em nome de uma coletividade, marcando, 
entretanto, seu discurso na impessoalidade (forma pronominal), inserindo-se também no todo social através do uso de um vocabulário (substantivos) que dê conta dos vários segmentos sociais. A saber:

Nos países onde impera o Estado de Direito todos assumem responsabilidades, todos conhecem os limites de suas atribuições,..., todos opinam livre e despreocupadamente, todos emitem conceitos e julgam publicamente os poderosos do dia, enfim todos fazem opções (PINTO, 1972, p. 01).

Quando o intelectual, o estudante, o empresário, o operário se recusam a participar da vida política brasileira não é porque a esta negam validade e nela não crêem, vendo-a reduzida a simples força coonestante (PINTO, 1972, loc. cit.).

O Governo Brasileiro, como de resto todos os governos autoritários, impõe-nos leis justas e injustas... (ibid., p. 03)

Utiliza-se também das marcas lingüísticas argumentativas sentenças afirmativas - constituindo-se nas modalidades assertivas (PETRI, 1994, p. 78) que dão o tom de presencialidade da carga ideológica que defendia, naquele momento discursivo, bem como o tom contundente com que marca sua fala na intenção de produzir um efeito bombástico no auditório - os operadores argumentativos- na forma de adjetivos. Esse conjunto de procedimentos argumentativos, segundo PETRI (1994, p. 71), "pertencem as manobras ou estratégias discursivas, utilizadas pelo locutor com a intenção de produzir determinadas interpretações". Senão vejamos:

Neste País o desrespeito à lei não é privilégio dos terroristas, mas também do Governo( PINTO, 1972, p. 02). 
Seus oficiais da dignidade de guardiães da Pátria, verse-iam levados à humilhante condição de beleguins ou inquisitores e, mesmo de sequazes ou esbirros de camarilha sem fé e sem patriotismo"( PINTO, 1972, loc., cit.).

O caráter polifônico também está presente em seu discurso, uma vez que se apropria da fala do General Augusto César Muniz e de parte do editorial do jornal O Estado de São Paulo para consubstanciar as teses levantadas e defendidas pelo locutor. Veja-se,

A verdade é que se o 'País está sendo objeto da inveja, cobiça e cupidez de outros Estados, por tradições imperialistas e dominadoras, ora agressivos ora subversivos na maneira de agir' como assevera, não é menos verdade que aquilo que para ele é, apenas uma 'grande preocupação que me punge a alma de patriota', já se constitui em uma realidade em nosso País (PINTO, 1972, p. 02).

Que a transformação das Forças Armadas em milícia ou guarda pretoriana nunca se dá por ato formal ou com plena consciência e concordância de seus membros. Simplesmente vai acontecendo, aos poucos, até que um dia se verifica sua evidência, até mesmo sem culpados ou responsáveis diretos (ibid., p. 04).

\subsection{O RECEPTOR}

O auditório, o TU da cena enunciativa, segundo Perelman, é fundamental na constituição argumentativa, pois é para aonde se dirige o discurso, objetivando a adesão das teses defendidas pelo emissor (L).

É, portanto, a natureza do auditório ao qual alguns 
argumentos podem ser submetidos com sucesso que determina $\mathrm{m}$ ampla medida tanto o aspecto que assumirão as argumentações quanto o caráter, o alcance que lhe serão atribuídos (PERELMAN, 1996 , p. 33)

Nesta cena, o alocutário (AL), constituído pelo presidente da república, no caso o General Emílio Garrastazu Médici, e pelos outros parlamentares, integra a relação da interlocução -emissor/ receptor-, buscando influenciar nas opiniões e nas futuras decisões parlamentares e governamentais que, porventura, tivessem que ser tomadas.

Observa-se, outrossim, que o locutor também almeja atingir outros receptores não explicitados nos discursos, ou seja, receptores não-alocutários. Trata-se dos meios de comunicação que, mesmo sofrendo os agravos da censura, poderiam, de certa forma, publicar seu manifesto e daí atingir um auditório bem maior do que aquele restrito à Câmara Federal.

\section{CONCLUSÃO}

O discurso, ora apresentado, faz parte de uma série de outras manifestações escritas do político Francisco José Pinto dos Santos no período que foi representante popular na Câmara Federal, nas décadas de 70 e 80 , tendo sempre como temática central a denúncia e a irreverência frente aos governos da época.

O período da ditadura militar, iniciado na década de $60 \mathrm{e}$ estendendo-se até meados dos anos 80 , tornou-se o palco central das questões sócio-políticas trazidas por Chico Pinto em seus discursos. $\mathrm{O}$ exército, particularmente, chamou mais a atenção dos políticos de esquerda, pois representava o órgão repressor por excelência, disseminando por todo o país terror e medo a quem se posicionasse de forma contrária à nova ordem estabelecida.

Em toda sua produção escrita, Francisco Pinto ressalta a importância da liberdade de opinião e de expressão, reivindicando sempre o respeito às leis e às garantias individuais. Esse discurso, especialmente, é o retrato dessa postura ideológica, no qual 
combate fortemente às ações de força das Forças Armadas e o aniquilamento do estado democrático.

Estudar, portanto, os discursos do político feirense Francisco Ferreira Pinto dos Santos, representa, além do resgate da memória política do país de do Estado da Bahia, uma importante fonte histórica e uma importante fonte de estudo dos procedimentos argumentativos, haja vista a forte tônica elocutória dos seus discursos. O estudo retórico, assim, tem nessas produções escritas, um farto campo de análise e pesquisa, salientando-se as marcas lingüísticas de uma produção textual esteticamente viável.

Vale mais uma vez salientar que esse discurso faz parte do projeto de pesquisa, iniciado no ano corrente, no programa de pós-graduação em Lingüística Aplicada da Universidade de Federal da Bahia e, por isso, mesmo não foi possível aprofundar as análises no campo retórico, apresentando-se um panorama geral quanto as análises argumentativas.

\section{EXÉRCITO: NEM GUARDA PRETORIANA NEM TROPA DE ASSALTO SS}

18 DE AGOSTO DE 1972

O SR. FRANCISCO PINTO - MDB-BA- Sr. Presidente, Srs. Deputados, se outros elementos não existissem para diferençar o regime democrático dos ditatoriais ou semiditatoriais, o medo serviria para distingui-los.

Nos países onde impera o Estado de Direito todos assumem responsabilidades, todos conhecem os limites de suas atribuições, do que é proibido, todos opinam livre e despreocupadamente, todos emitem conceitos e julgam publicamente, os poderosos do dia, enfim, todos fazem opções. Nos Estados totalitários alguns dão ordens e poucos opinam. A maioria ou concorda com as determinações impostas, elogiando-as sempre, ou se postam 
silenciosas e inermes, mas sempre amendrontadas. Os que opinam discordando, mas conscientes dos riscos, o fazem sem esperar solidariedades. Ninguém quer se comprometer com vozes discordantes. E o medo não está longe, ele se encontra presente entre nós, nas mais variadas camadas da população e se apresenta sob as mais variadas formas.

Quando o intelectual, o estudante, o empresário, o operário se recusam a participar da vida política brasileira não é só porque estas negam validade e nela não crêem, vendo-a reduzida a simples força coonestante. Em verdade se utilizam deste argumento para justificar sua passividade, diante dos riscos que não negam, mas ficam bem com a sua consciência, porque amuletados nos seus próprios argumentos se dedicam tão só a atividade profissional, onde se realizam economicamente sem opinar sobre determinados valores incorporados à civilização ocidental, mas que o governo brasileiro teima e negar e destruir.

Se é um militar que fala, e experiência tem aconselhado a todos que dele não se deve discordar e a prudência recomenda nem elogiar é bom.

Mas é impossível silenciar depois de ler o pronunciamento do General Augusto César Muniz de Aragão, conhecido pelo seu destemor e pelas suas qualidades de disciplinador, as vezes até exagerado no respeito aos cânones hierárquicos. Ele fez um discurso analítico, polêmico e de certo modo angustiado, ao menos, cheio de preocupação. Os riscos por que estamos passando no Brasil só não enxerga quem não quer. O ilustre militar os aponta as claras e, como conhecedor profundo das Forças Armadas e talvez por isto mesmo, é mais otimista que muitos outros. Entende que as tradições democráticas das Forças Armada não serão desmentidas, esquecido apenas, que há momentos em que o medo se generaliza, a todos atingindo indiscriminadamente.

A verdade é que se o "País está sendo objeto da inveja, cobiça e cupidez de outros Estados, por tradições imperialistas e dominadoras, ora agressivos ora subversivos na maneira de agir" como assevera, não é menos verdade que aquilo que para ele é, 
apenas uma "grande preocupação que me punge a alma de patriota", já se constitui em uma realidade em nosso País. Quando aconselha que as Forças Armadas precisam "encontrar-se disciplinadas, adestradas e aptas, prontas para a ação contra o desrespeito a lei, a perturbação da harmonia entre as classes, o exercício do arbítrio e a prática da violência" faz uma advertência não para o futuro remoto, mas para o presente. Neste País o desrespeito à lei não é privilégio dos terroristas, mas também do Governo. O que é importante no regime democrático não é só a existência da lei e a existência do seu respeito, porque nas ditaduras de direita ou esquerda a lei também existe e a força querem-nas respeitada. Nestas, determina-se obediência ilimitadas. $\mathrm{O}$ que caracteriza o regime democrático é a existência de leis justas e legítimas, de leis que traduzam a média da consciência coletiva. O Governo brasileiro, como de resto todos os governos autoritários, impõemnos leis justas e injustas e a todas querem que juremos obediência e de todos exigem o seu cumprimento. Querem estes governos que os militares sejam fiéis executores destas leis; e quando estes passam a impor ao povo o cumprimento de leis ditadas por minorias arbitrárias, eles se desviam de suas verdadeiras missões, esquecendose "de suas nobres tradições" e deformando assim a prática de sua função constitucional, para tornar-se milícia, guarda pretoriana ou tropa de assalto SS. Seus oficiais da dignidade de guardiães da Pátria, ver-se-iam levados à humilhante condição de beleguins ou inquisitores e, mesmo de sequazes ou esbirros de camarilhas sem fé sem patriotismo. Tal hipótese - continua - constitui terrível dilema: para fugir ao perigo comunista seria a Nação mergulhada em regime de extrema direita, igualmente policialesco e violento. Tal alternativa não admite opção.

Como o ilustre general crê na sua corporação, acredita "que isto jamais ocorreria no Brasil devido à vocação cívica e democrática das Forças Armadas". Externa no entanto, no início de sua oração, "a grave preocupação que me punge a alma patriota", 
preocupação que é de todos que acompanham o processo a que estamos sendo conduzidos.

Sem ser um discurso político no sentido "strito", foi objeto de comentário por parte de um dos maiores articulistas brasileiros, o Senhor Carlos Castelo Branco. Não foi sem razão que o "Estado de São Paulo", sempre preocupado em preservar as legítimas conquistas que a revolução burguesa nos legou, em mais de um editorial, inclusive o de 13 do corrente, faz referência àquele discurso que teve uma dimensão nacional, esclarecendo "que a transformação das Forças Armadas em milícia ou guarda pretoriana nunca se dá por ato formal que com a plena consciência e concordância de seus membros. Simplesmente vai acontecendo, aos poucos, até que um dia se verifica sua evidência, até mesmo sem culpados ou responsáveis diretos”.

O que não nos desespera, nesta hora, Sr. Presidente, é a confiança que temos no povo e na proclamada e reconhecida tradição de inequívoca lealdade das Forças Armadas à causa democrática. (Muito bem.)

\section{REFERÊNCIAS}

ALTHUSSER, Louis. Aparelhos ideológicos do estado. Tradução: Walter José Evangelista e Ma. Laura Viveiros de Castro. 6. ed. Rio de Janeiro: Graal.1992.

ARISTÓTELES. (Sec. V) Arte Retórica e Arte Poética. Tradução: Antonio Pinto de Cavalho. Clássicos Garnier da Difusão Européia do Livro: SP. 1979.

BAKHTIN, Mikhail. (V.N. Volochinv). Marxismo e filosofia da linguagem. Tradução: Michel Lahud e Yara Frateschi Vieira. 7. ed. São Paulo: Huicitec. 1995.

BRANDÃO, Helena Nagamine. Introdução à análise do discurso. 6. ed. Campinas: UNICAMP. 1997. 
CITELI, Adilson. Linguagem e Persuasão. Série Princípios. São Paulo: Ática. 2001.

D’ARAUJO, Ma. Celina; CASTRO, Celso (Org.). Ernesto Geisel. Rio de Janeiro: Editora Fundação Getúlio Vargas. 1997.

FIORIN, J.L. Elementos de análise dos discurso. São Paulo: Contexto/EDUSP. 1989.

GASPARI, Elio. A ditadura escancarada. São Paulo: Companhia das Letras, 2002.

GILES, Thomas Ransom. 1937 Estado, poder, ideologia. São Paulo: EPU. 1985.

GOMES, João Carlos Teixeira. Memória das trevas. São Paulo: Geração Editorial. 2001.

HABERT, Nadine. A década de 70: Apogeu e crise da ditadura militar brasileira. São Paulo: Ática. 1994.

HALLYDAY, Tereza Lúcia (Org.). Atos retóricos: mensagens estratégicas de políticos e igrejas. São Paulo: Sumus. 1988.

KOCH, Ingedore G. V. Argumentação e Linguagem. São Paulo: Cortez. 1984.

MAINGUENEAU, Dominique. Novas Tendências em análise do discurso. Tradução: Freda Indursky. 3. ed. Campinas, SP: Pontes: Editora da Universidade Estadual de Campinas. 1997.

. Os termos-chave da análise do discurso. Tradução: Maria Adelaide P. P. Coelho da Silva. Lisboa: Gradiva. 1997.

. Análise de Textos de Comunicação. Tradução: Cecília 
P. de Souza-e-Silva. São Paulo: Cortez. 2001.

MOSCA, Lineide do L. Salvador (Org.). Retóricas de ontem e de hoje. São Paulo: Humanitas Editora / FFLCH/USP. 1997.

ORLANDI, Eni P. A linguagem e seu funcionamento: as formas do discurso. 4. ed. Campinas, SP: Pontes. 2001.

. Discurso e Texto: formação e circulação dos sentidos. Campinas, SP: Pontes. 2001.

- Análise de discurso: princípios e procedimentos. Campinas, SP: Pontes, 4. ed., 2002.

OSAKABE, Haquira. Argumentação e discurso político. 2. ed. São Paulo: Martins Fontes. 1999.

PÊCHEUX, Michel. O discurso: estrutura ou acontecimento. Tradução: Eni Puccinelli Orlandi. 2. ed. Campinas, SP: Pontes. 1997.

PERELMAN, C; OLBRECHTS-TYTECA, L. Tratado da argumentação: a Nova Retórica. Tradução: Maia Ermantina Galvão G. Pereira. São Paulo: Martins Fontes. 1996.

PERELMAN, C. Retóricas. Tradução: Ma. Ermantina Galvão G. Pereira. São Paulo: Martins Fontes. 1997.

- Lógica Jurídica: nova retórica. Tradução: Vergínia K. Pupi. São Paulo: Martins Fontes. 1998.

PETRI, Maria Constantino. Argumentação lingüística e discurso jurídico. São Paulo: Selinunte. 1994. 
69

PLEBE, Armando. Manual de Retórica. São Paulo: Martins Fontes. 1992. 